\title{
An external tag for fish: tagging effects in different fish size classes and its influence on growth performance and hematology of Lophiosilurus alexandri (Siluriformes: Pseudopimelodidae)
}

\author{
Túlio P. Boaventura ${ }^{1}$, Viviane S. B. Gil ${ }^{1}$, Camila S. B. Gi1², \\ Anderson M. Peres ${ }^{3}$ and Ronald K. Luz ${ }^{1}$
}

This study tested an external tag for juveniles of Lophiosilurus alexandri and measured the effects of tagging in different size classes of fishes. Experiment 1 evaluated the retention rate and influence of the tag on survival and growth of three hundred fishes divided Small, Medium and Large size classes. After 90 days of experiment the fishes had $100 \%$ survival and the tag had a higher retention rate for animals of the Large size class. Experiment 2 evaluated the tag's influence on hematology parameters of forty-two fishes at 5, 10 and 30 days post-tagging. In this experiment both tagged and untagged animals experienced $9.4 \%$ mortality. The hematocrit was higher on the $30^{\text {th }}$ day for tagged animals than for untagged animals. No difference was observed for leukocytes, plasma protein, erythrocytes and mean corpuscular volume. It was concluded from Experiment 1 that the tag reduced growth performance when applied to small sized juvenile L. alexandri, and that the tag retention rate increased with increasing animal size. Among the hematological parameters studied for juveniles on the Experiment 2 the tag only influenced the hematocrit parameters, which shows that the tag can be used without considerable influence on the hematological parameters of juvenile L. alexandri.

Keywords: Catfish, Identification, Pacamã, Physiology, Repopulation, Retention.

Esse estudo testou a utilização de marcadores externos em juvenis de Lophiosilurus alexandri, assim como o tamanho mínimo ideal do peixe para marcação. No experimento 1 foi avaliado a taxa de retenção e a influência do marcador sobre a sobrevivência e crescimento dos peixes divididos por tamanho nas classes: Pequeno, Médio e Grande. Após 90 dias, os peixes apresentaram $100 \%$ de sobrevivência e uma taxa de retenção mais elevada para os animais classificados como grandes. O segundo experimento avaliou a influência do marcador sobre os parâmetros hematológicos dos animais após 5, 10 e 30 dias da marcação. Neste experimento, foram observados valores mais elevados para o hematócrito no $30^{\circ}$ dia para os animais marcados, enquanto nenhuma diferença foi observada para leucócitos, proteína plasmática, eritrócitos e volume corpuscular médio. Concluiu-se o que o marcador reduziu a taxa de crescimento dos animais menores, e que a taxa de retenção aumentou com o aumento do tamanho do animal. Dos parâmetros hematológicos avaliados, o marcador influenciou apenas no valor do hematócrito, o que mostra que o marcador pode ser usado sem considerável influência nos parâmetros hematológicos do $L$. alexandri.

Palavras-chave: Bagre, Identificação, Fisiologia, Pacamã, Repovoamento, Retenção.

\section{Introduction}

Increasing commercial (FAO, 2016) and recreational (Johnston et al., 2007) fishing, along with pollution and alterations of river courses through the construction of large reservoirs for hydroelectric plants, have placed natural fishe- ries resources under strong pressure (Auer, 1996; Agostinho et al., 2010; Mcdougall et al., 2014). As a result, several countries have developed interests in promoting stocking programs to restore fish stock and to prevent the extinction of endangered species (Svåsand et al., 2000; Steffensen et al., 2010; Kawamura et al., 2012).

\footnotetext{
${ }^{1}$ Laboratório de Aquacultura da Universidade Federal de Minas Gerais (UFMG), Av. Antônio Carlos, 6627, Pampulha, 31270-901 Belo Horizonte, MG, Brazil. (RKL) luzrk@yahoo.com, Dhttps://orcid.org/0000-0002-1021-5772 (corresponding author), (TPB) tuliopb1@ hotmail.com, Dhttps://orcid.org/0000-0002-6143-5417, (VSBG) vivianebreygil@hotmail.com, Dhttps://orcid.org/0000-0002-6037-8203 ${ }^{2}$ Fundação Comunitária de Ensino Superior de Itabira (FUNCESI), Rua Venâncio Augusto Gomes, 50, Lage de Cima, $35900-842$ Itabira, MG, Brazil. camilabreygil@gmail.com, ㄴohttps://orcid.org/0000-0002-0767-3123

${ }_{3}^{3}$ Laboratório de Ecologia Química de Insetos Vetores da Universidade Federal de Minas Gerais (UFMG), Av. Antônio Carlos, 6627, Pampulha, 31270-901 Belo Horizonte, MG, Brazil.Amp.dig@gmail.com, Dhttps://orcid.org/0000-0001-8945-3855
} 
Despite the efforts of repopulation programs, few studies have been carried out to assess their effectiveness (Agostinho et al., 2010; Barroca et al., 2015). One of the tools used for this type of verification and evaluation is the use of tags (Svåsand et al., 2000) that facilitate the identification of individual fish after their release (Specziár, Turcsányi, 2014).

A number of fish tags have been described in the literature (Griffiths, 2002; Gibbons, Andrews, 2004; Woods, MartinSmith, 2004; Brennan et al., 2007; Zeeh, Wood, 2009), and they can be classified as internal or external (Navarro et al., 2006; Brewer, Norcross, 2012). Internal tags can have high retention rates for some species of fish (Ward et al., 2008), however, they require the use of special equipment to read the information contained in the tags (Smith et al., 2017). External tags, on the other hand, have advantages as low cost, facility of application and excellent visibility (Griffiths, 2002). Depending on the species of fish evaluated, external tags may have a low retention rate, clogging and grabbing risks, swimming influences, reduced growth and insults at the site of application, factors that contribute to the low recapture rate (Jepsen et al., 2015). The information contained in these tags can allow collaboration between fishers and researchers, in which some kind of reward (Alves, 2007; Rudershausen et al., 2014) can be offered to the fishers when catching a tagged fish t oencourage the relay of information to researchers (Sumpton et al., 2008).

Ideal tags should not influence fish performance, which can be assessed through growth performance and survival (Woods, Martin-Smith, 2004). However, each type of tag can influence fish performance differentially (Navarro et al., 2006). Therefore, it is necessary the evaluation of the tag's effects on the fish performance in a controlled environment before being used in natural environment (Frederick, 1997; Winner et al., 1999; Booth, Weyl, 2008).

Hematology is a tool of great importance for assessing animal welfare, physiological status, disease and stress (Krystan, Grant, 2015). Under conditions of stress and increased physical effort, fish may increase the concentration of erythrocytes and hematocrits to improve blood oxygenation (Acerete et al., 2004). Leukocytes are defense cells responsible for monitoring possible infections and tissue damage (Tavares-Dias, de Moraes, 2007) and may present changes due to stress (Adeyemo, 2007). Plasma protein plays an important role in the osmotic regulation of blood and can be used as an indication of homeostatic disturbance (Verdegem et al., 1997). Thus, it is evident the need to evaluate the hematology of animals submitted to handling conditions such as marking.

Pacamã, Lophiosilurus alexandri Steindachner, 1876, family Pseudopimelodidae, order Siluriformes (Barros et al., 2007), is a sedentary piscivorous fish species endemic to the Rio São Francisco Basin in Brazil (Cardoso et al., 1996). This species is nocturnally active (Kitagawa et al., 2015) and is listed in the Brazil Red Book of Threatened Species of Fauna as "vulnerable to extinction" (ICMBio, 2016). Thus, L. alexandri has been the subject of repopulation programs (Sato, 2014).
The objective of this work was to evaluate a new visually observable external tag for fish measuring the tagging effects on different size classes of fishes and the influence on zootechnical and hematological parameters of $L$. alexandri.

\section{Material and Methods}

The study was carried out in the Laboratório de Aquacultura (LAQUA) of the Universidade Federal de Minas Gerais (UFMG), through two experiments. During the experiments, fish were fed commercial extruded feed containing 38\% crude protein as 3-4 mm diameter pellets delivered to apparent satiation twice daily (08:00 am and 04:00 pm). After 30 minutes of feeding, feces and unconsumed food were siphoned. Water quality parameters were measured every three days: temperature and $\mathrm{pH}$ were measured using a COMBO (HANNA brand) portable $\mathrm{pH}$ meter; dissolved oxygen (DO) with a digital oximeter (HANNA brand); and ammonia with a colorimetric kit (LabconTest).

For tagging fish in both experiments, the harpoon tags that are supposed to fix the tag to a spine(fin) inside the fish, applicator and application methodology used followed the methodology deposited with the patent: BR1020170075770 titled MARCADOR VISUAL EXTERNO PARA IDENTIFICAÇÃO DE PEIXES E APLICADOR, which is shown in Fig. 1. The tag was manufactured from polyethylene terephthalate modified with glycol (PETG), weighed 0.16 grams, and was applied using a $30 \mathrm{~mm}$ long and $1.5 \mathrm{~mm}$ diameter needle coupled to a metal rod. For application of the tag the needle was inserted approximately $5 \mathrm{~mm}$ into the right side of the musculature near the dorsal fin.

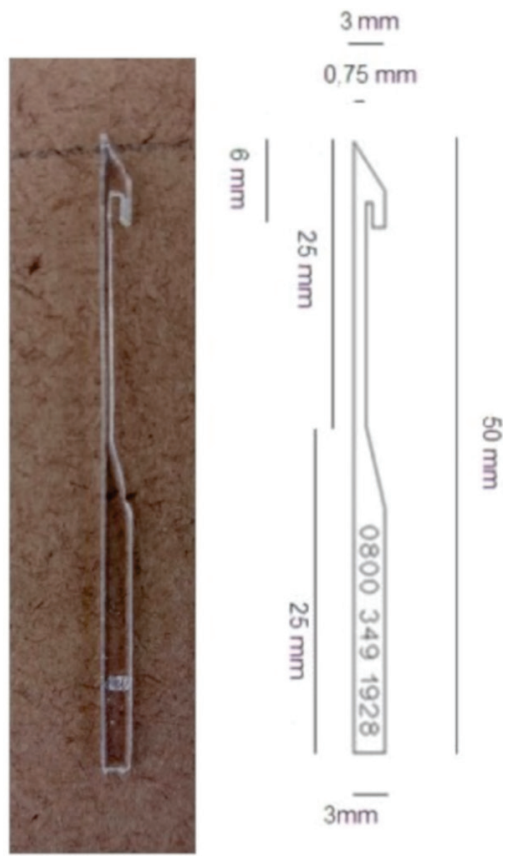

Fig. 1. Visual tag for fish described in the patent BR1020170075770. 
The species used in this study were offspring frombroodstock wild-caught from the São Francisco River. The broodstock were adapted to conditions of captivity in the Laboratory of Aquaculture (Laqua) of the Universidade Federal de Minas Gerais (UFMG) for nine years. The representative material of the species used in this study was deposited in the collection of the Coleção Ictiológica at the Museu de Ciências Naturais da PUC Minas (MCNIP 3217).

Experiment 1. Ideal minimum size for tag application, retention rate and influence on performance of juvenile of $\boldsymbol{L}$. alexandri. This experiment was carried out according to protocols approved by the Comissão de Ética no Uso de Animais (CEUA; Ethics Committee on Animal Use) of UFMG (Protocol 243/2017).

Hatchery reared juvenile $L$. alexandri, previously produced in LAQUA, were classified into three size classes after weighing with an analytical scale (Marte AD $20000.01 \mathrm{~g}$ precision) and measuring length with a digital caliper (Gama - precision $0.01 \mathrm{~mm}$ ) (Tab. 1). After classification, the juveniles were acclimatized for seven days and then distributed among $12200 \mathrm{~L}$ tanks with a useful volume of $180 \mathrm{~L}$ of water each such that there were four replicates of each size class. Each tank received 25 animals. For retention rate and performance evaluations, 15 animals from each tank were tagged with the external tag while the remaining 10 (control) remained untagged. A greater number of tagged animals was used to account for the possibility of tag loss and the subsequent reduction in the number of tagged animals.

Tab. 1. Mean and standard deviation of the weight and length of the Lophiosilurus alexandri used in the different size classes.

\begin{tabular}{lcccc}
\hline $\begin{array}{c}\text { Size } \\
\text { classes }\end{array}$ & Weight $(\mathrm{g})$ & Length $(\mathrm{cm})$ & $\begin{array}{c}\text { Animals tagged } \\
\text { by treatment }\end{array}$ & $\begin{array}{c}\text { Animals untagged by } \\
\text { treatment (control) }\end{array}$ \\
\hline Smal & $14.50 \pm 0.63$ & $10.58 \pm 0.63$ & 60 & 40 \\
Medium & $23.95 \pm 1.76$ & $11.71 \pm 0.52$ & 60 & 40 \\
Large & $31.96 \pm 3.50$ & $13.50 \pm 0.60$ & 60 & 40 \\
\hline
\end{tabular}

The tanks were maintained in a water recirculation system with controlled water temperature of $27.66 \pm 0.40{ }^{\circ} \mathrm{C}$, DO of $6.38 \pm 0.46 \mathrm{mg} \mathrm{L}^{-1}, \mathrm{pH}$ of $8.34 \pm 0.04$ and total ammonia $<0.5$ $\mathrm{mg} \mathrm{L}^{-1}$. The photoperiod was maintained at 12 hours of light. The animals were observed over a period of 90 days. The tag retention rate was determined by Equation 1 based on daily observations of the animals. When a loose tag was noted in the tank, both the tag and the fish, indicated by the presence of the implant injury, were removed from the experiment to avoid distortions in the score of tagged versus untagged fish.

$$
\mathrm{RR}=(\mathrm{Tf} / \mathrm{Ti}) * 100
$$

Equation 1. Equation used to measure the retention rate of tags, where: $\mathrm{RR}$ is the retention rate, $\mathrm{Ti}$ is number of animals initially tagged and $\mathrm{Tf}$ is the number of tagged animals that remained.
After 90 days, the final weight (Wf) and the final length (Lf) of the fishes were measured. The weight gain (WG) and survivorship rate (SR) were calculated by the following equations:

$$
\mathrm{WG}=\mathrm{Wf}-\mathrm{Wi}
$$

Equation 2. Equation used to calculate weight gain (WG), where: Wf and Wi are the final and initial fish weight, respectively.

$$
\mathrm{SR}=(\mathrm{Nf} / \mathrm{Ni}) * 100
$$

Equation 3. Equation used to calculate the survivorship rate (SR), where: $\mathrm{Nf}$ is the final number of fish survivors, and $\mathrm{Ni}$ is the initial number of individuals.

Experiment 2. Influence of tag on hematology of juvenile L. alexandri. This experiment was carried out according to protocols approved by CEUA of UFMG (Protocol 25/2017 CEUA of UFMG). Forty-two juvenile L. alexandri (17.09 \pm $1.02 \mathrm{~cm}$ and $64.28 \pm 11.80 \mathrm{~g}$ ) were acclimated for 30 days in a $1000 \mathrm{~L}$ tank kept in a recirculation system with controlled water temperature of $27.64 \pm 0.41{ }^{\circ} \mathrm{C}, \mathrm{DO}$ of $6.45 \pm 0.47$ $\mathrm{mg} \mathrm{L}^{-1}, \mathrm{pH} 8.35 \pm 0.03$ and total ammonia $<0.5 \mathrm{mg} \mathrm{L}^{-1}$. The photoperiod was 12 hours of light. After acclimatization, 10 animals were randomly selected for blood analysis as an initial baseline. Of the remaining 32 animals, 16 received a tag and 16 remained untagged. These fish were divided into two $1000 \mathrm{~L}$ tanks under the previously described conditions, with eight tagged fish and eight untagged fish in each, in an experimental design with two treatments and 16 replicates, with each fish being considered a replicate. After five days, blood was collected from all tagged $(n=8)$ and untagged $(\mathrm{n}=8)$ fish from one of the two tanks. The same procedure was performed after 10 days for fish from the second tank ( $n=8$ tagged and $n=8$ untagged). After 30 days, all of the fish from both tanks were again sampled for blood. The retention rate of the tags and the mortality rate of the fish were monitored during the 30 days of the experiment.

For blood collection, each fish was restrained with a moist cloth and $1 \mathrm{~mL}$ of blood was acquired by venous puncture of the vertebral artery using $1 \mathrm{~mL}$ syringe containing $10 \%$ heparin. Aliquots of blood were used to determine total plasmatic protein (TPP), hematocrit (Htc), erythrocytes (Er) and leukocytes (Leuk). The hematocrit was determined by the microhematocrit method (Goldenfarb et al., 1971) using capillary tubes. After the determination of the hematocrit, the capillaries were broken above the plasma line, which was then placed in a refractometer (RTS-101ATC) to determine total plasmatic protein.

Counts of erythrocytes and leukocytes were performed according to the direct method of counting in a Neubauer chamber, after staining with Natt-Herrik dye in a hemocytometer and mean corpuscular volume (MCV) was calculated by Equation 4 . 


$$
\mathrm{MCV}=(\mathrm{Er} / \mathrm{Htc}) * 10
$$

Equation 4. Equation used to calculate mean corpuscular volume (MVC), where: Er is the number of erythrocytes and Htc is the hematocrit.

Statistical analysis. All data were tested for normality (Shapiro Wilk test) and homoscedasticity (Levene test). For normality, the hematocrit results were $\log (10)$ transformed. Hematological results between days were analyzed by ANOVA followed by the Tukey test at $5 \%$ probability. Data comparing the results between treatments for both hematological and performance were analyzed by Student's t-test. Tag retention rate throughout the days of Experiment 1 was analyzed by two-way ANOVA followed by Tukey test at 5\% probability. The software Infostat was used for all statistical analyses.

\section{Results}

Experiment 1. Comparing RR for the same size class over days (Fig. 2) revealed that the RR of the tags in the three fish classes decreased significantly $(P<0.05) 30$ days posttagging and remained similar until 60 days $(P>0.05)$. At 90 days post-tagging, the Medium size class had a RR similar $(P>0.05)$ to those at 30 and 60 days. The Large size class had RR like that at 60 days but different from that at 30 days, while the Small class had a lower RR at 90 days $(P<0.05)$ than at 30 and 60 days.

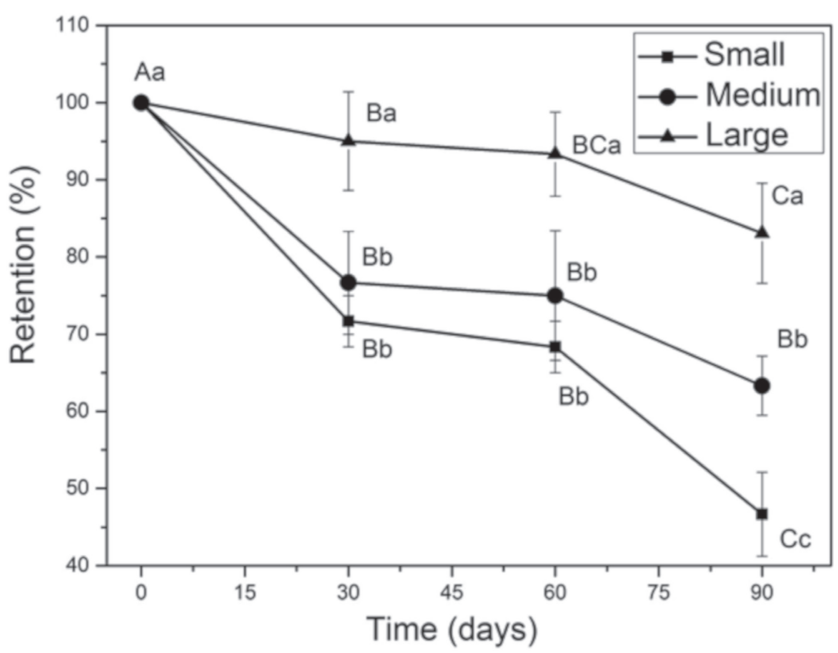

Fig. 2. Retention rate of tags for the different size classes of Lophiosilurus alexandri evaluated every 30 days for a period of 90 days. Means followed by different letters (uppercase between days and lowercase between sizes) differ significantly $(p<0.05)$ by two-way ANOVA followed by Tukey test.

Comparing RR of the different size classes for the same day revealed that the RR for the Large size class was higher $(P<0.05)$ than that of the Small and Medium classes for all the days evaluated. The RR for the Small and Medium size classes were similar $(P>0.05)$ at 30 and 60 days posttagging, while at 90 days the Medium size exhibited a higher RR $(P<0.05)$ than the Small size class.

Fig. 3a shows a photograph of a tagged fish of the Large size class at the end of 90 days, and in Fig. $3 \mathrm{~b}$ the scar caused by the detachment of the tag from a fish of the Small size class can be seen. Animals that were withdrawn from the experiment due to tag loss recovered and showed $100 \%$ survivorship during the period of the experiment. Comparing the performances of the tagged and untagged fish (Tab. 2) of the same size class revealed that fish of the Small size class had lower WG and Wf $(P<0.05)$ than the untagged animals, while Lf was similar $(P>0.05)$. There were no differences $(P>0.05)$ in performance for the fish of the Medium and Large size classes.

Tab. 2. Weight gain and final weight and lengthof the $L o$ phiosilurus alexandri in the different size classes after 90 days. Weight gain (WG), final weight (Wf) and final length (Lf). Means for tagged and untagged fish of the same size class followed different letters differ significantly $(p<0.05)$ by the Student t-test.

\begin{tabular}{|c|c|c|c|c|c|c|}
\hline \multirow{2}{*}{$\begin{array}{c}\text { Size } \\
\text { classes }\end{array}$} & \multicolumn{2}{|c|}{ WG (g) } & \multicolumn{2}{|c|}{ Wf $(g)$} & \multicolumn{2}{|c|}{ Lf total $(\mathrm{cm})$} \\
\hline & Untagged & Tagged & Untagged & Tagged & Untagged & Tagged \\
\hline Smal & $23.2 \pm 0.6 \mathrm{a}$ & $21.0 \pm 0.4 \mathrm{~b}$ & $38.5 \pm 0.6 \mathrm{a}$ & $36.4 \pm 0.4 b$ & $13.0 \pm 0.2 \mathrm{a}$ & $12.6 \pm 0.4 \mathrm{a}$ \\
\hline Medium & $27.4 \pm 3.6 \mathrm{a}$ & $26.4 \pm 2.4 \mathrm{a}$ & $51.8 \pm 3.6 \mathrm{a}$ & $50.8 \pm 2.4 \mathrm{a}$ & $15.82 \pm 2.1 \mathrm{a}$ & $14.4 \pm 0.2 \mathrm{a}$ \\
\hline Large & $42.4 \pm 5.5 \mathrm{a}$ & $45.1 \pm 3.3 \mathrm{a}$ & $76.0 \pm 5.5 \mathrm{a}$ & $78.8 \pm 3.2 \mathrm{a}$ & $17.55 \pm 0.3 a$ & $17.7 \pm 0.2 \mathrm{a}$ \\
\hline
\end{tabular}

Experiment 2. Deaths of one tagged and one untagged fish were recorded on the $10^{\text {th }}$ and the $12^{\text {th }}$ day of the experiment, respectively. In addition, tag loss of one fish was observed on the $14^{\text {th }}$ day, thus yielding a RR of $93.33 \%$. Both, fish mortality and tag detachment lead to a total of 15 untagged and 14 tagged fishes after 30 days of experiment.

Fig. 4a shows that the erythrocyte count exhibited no difference $(P>0.05)$ between tagged and untagged fish. However, there was variation among the different days analyzed with higher values $(P<0.05)$ at 5 and 10 days and lower values at 30 days, whether fish were tagged or not. At the beginning of the experiment the fish had intermediate levels.

Leukocytes (Fig. 4b), total plasmatic protein (Fig. 4c) and MCV (Fig. 4d) did not differ between tagged and untagged fish over time $(P>0.05)$.

Regarding hematocrit (Fig. 4e), there was an increase for both the tagged and untagged fish on the fifth day post-tagging $(P<0.05)$. On the $10^{\text {th }}$ day, the hematocrit of the untagged fish remained higher $(P<0.05)$ than the basal level, while the values for tagged fish were similar to the base line $(P>0.05)$. On the $30^{\text {th }}$ day, the untagged fish had lower levels $(P<0.05)$ than those recorded previously, whereas tagged fish had hematocrit levels similar to the basal treatment and different $(P<0.05)$ from the tagged fish on days 5 and 10 . The hematocrit only differed $(P<0.05)$ between tagged and untagged fish on the thirtieth day, when tagged fish had higher values. 


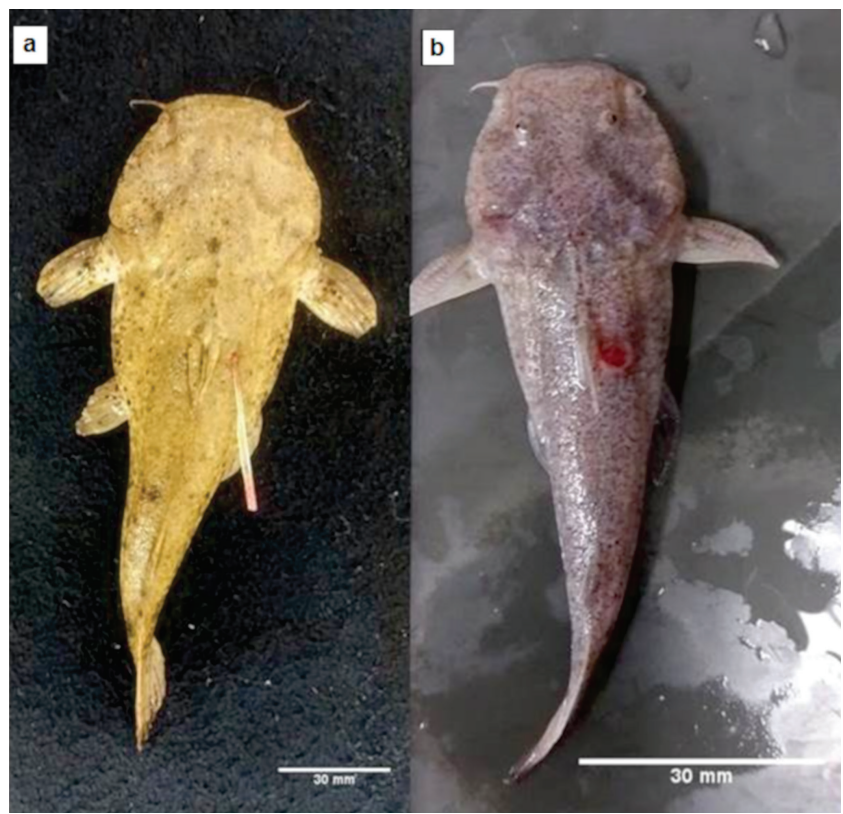

Fig. 3. Photograph of tagged Lophiosilurus alexandri. a. Large-size class animal after 90 days post-tagging. b. Small-size class animal with wound caused after tag detachment during the experiment. Scale bar $=30 \mathrm{~mm}$.

\section{Discussion}

There was no mortality of tagged and untagged fishes in Experiment 1, however, there were deaths of one tagged and one untagged individual in Experiment 2. These results indicate that the external tag can be used with juvenile $L$. alexandri, and that the observed mortality may just be due to an effect of the conditions of cultivation. Gil et al. (2017) compared the survival rate of juvenile Argyrosomusregius $(83.7 \pm 24.5 \mathrm{~g}$ and $19.5 \pm 1.9 \mathrm{~cm})$ and found lower survivorship (60\%) for animals tagged with an abdominal T-bar, and higher survivorship (83.3\%) for fish tagged with an anchor T-bar, which were similar to the untagged animals. Studying Lutjanuscampechanus (43.7 $\pm 5.6 \mathrm{~g}$ ), Phelps, Rodrigues (2011) found that fish tagged or not with an abdominal T-bar, PIT tag and mandibular tag for 150 days did not differ in survivorship.

The highest retention rate of the tags recorded in the present study was for fish of the Large size class during the entirety of Experiment 1 . This finding may be due to the fact that larger fish have a greater amount of muscle at the application site. The RR obtained was expected since it was not found in the literature, studies with high retention rates for external tags applied in small animals. Based on this we suggest the application of the tag in juveniles of L. alexandri larger than $13.50 \pm 0.60 \mathrm{~cm}$ and $31.96 \pm 3.50 \mathrm{~g}$ to ensure better retention rates.

Smith et al. (2017) compared the retention rates of PIT and T-bar tags in Coregonus sardinella (13.6-15.8 cm and 18.3-31.6 g) using different tagging protocols (with and without anesthesia followed by baths of salt for recuperation from handling at concentrations of 10 and $3 \mathrm{mgL}^{-1}$ ). These authors recorded mean retention rate for the T-bar treatment of $76 \%$ after 30 days post-tagging and variation among protocols of 25 to $45 \%$ after 60 days, while the PIT tag treatment had $100 \%$ retention in all the treatments. With blue catfish (Ictalurus furcatus) of $36.4 \pm 0.1 \mathrm{~cm}$ kept in excavated ponds for six months, Bodine, Fleming (2014) documented a retention rate of $94 \%$ for T-bar tags at two months and $76 \%$ at six months, while for PIT tags they recorded $100 \%$ retention. Thus, it is evident that the efficiency of a tag is related to the type of tag, the species tagged and the size of the fish, as well as the management methods employed.

In the present study, the lower growth performance found only for the Small size class of tagged fish compared to untagged fish of the same size may be related to the greater proportion of tag weight relative to body weight, which represented on average: $1.15 \%, 0.67 \%$ and $0.5 \%$ of dry weight for Small, Medium and Large size classes, respectively. There is no well-defined relationship between tag weight and animal body mass, so this variation may be due to the type of tagging and the species studied (Jepsen et al., 2015). Some studies recommend the use of taggers weighing less than $2 \%$ of an animal's weight in the air (Jepsen et al., 2003), others recommend an even lower ratio (1.25\%) (Counihan, Frost, 1999; Sutton, Benson, 2003), while other authors challenge this rule and suggest higher values (Brown et al., 1999; Smircich, Kelly, 2014). Even using smaller tagss than those recommended in the literature, the present study found fish of the Small class to have lower growth performance, indicating that this tag should be avoided for small fish and that it may need to be adjusted or a new model developed for this size class of fish. The external tag in a fish can cause imbalance, wounds (Halls, Azim, 1998) and infections due to the friction of the tag with water (Thorsteinsson et al., 2002). It can result in low rates of tag retention, fish survival and growth (Rikardsen, 2000; Rikardsen et al., 2002; Strand et al., 2002). Lophiosilurus alexandri is a lentic and bottomdwelling species, for which swimming was recorded only at the time of feeding. However, friction generated between the tag and water during swimming was minimal and only affected growth performance of smaller fish. Greenstreet, Morgan (1989) studied the use of external ultrasonic tags with three sizes of Atlantic salmon (Salmo salar) and observed a loss of body mass for the smaller animals $(>16.0$ $\mathrm{cm}$ ), lower growth performance for the average animals (between 16.0 and $18.0 \mathrm{~cm}$ ), and similar the control growth performance for larger animals $(>18.0 \mathrm{~cm})$. Rikardsen et al. (2002) compared the retention rate and influence on performance of two visual tags with the Arctic trout (Salvelinus alpinus) of 17.0-20.9 cm, and documented a retention rate of $94 \%$ for Floy tags and $78 \%$ for VI alpha tags 160 days post-tagging. However, the authors found lower growth rate for animals tagged with Floy tags.

Animals that experienced tag detachment and were transferred to another tank during the period of the experimental recovered from the injury caused by the tag and showed no 

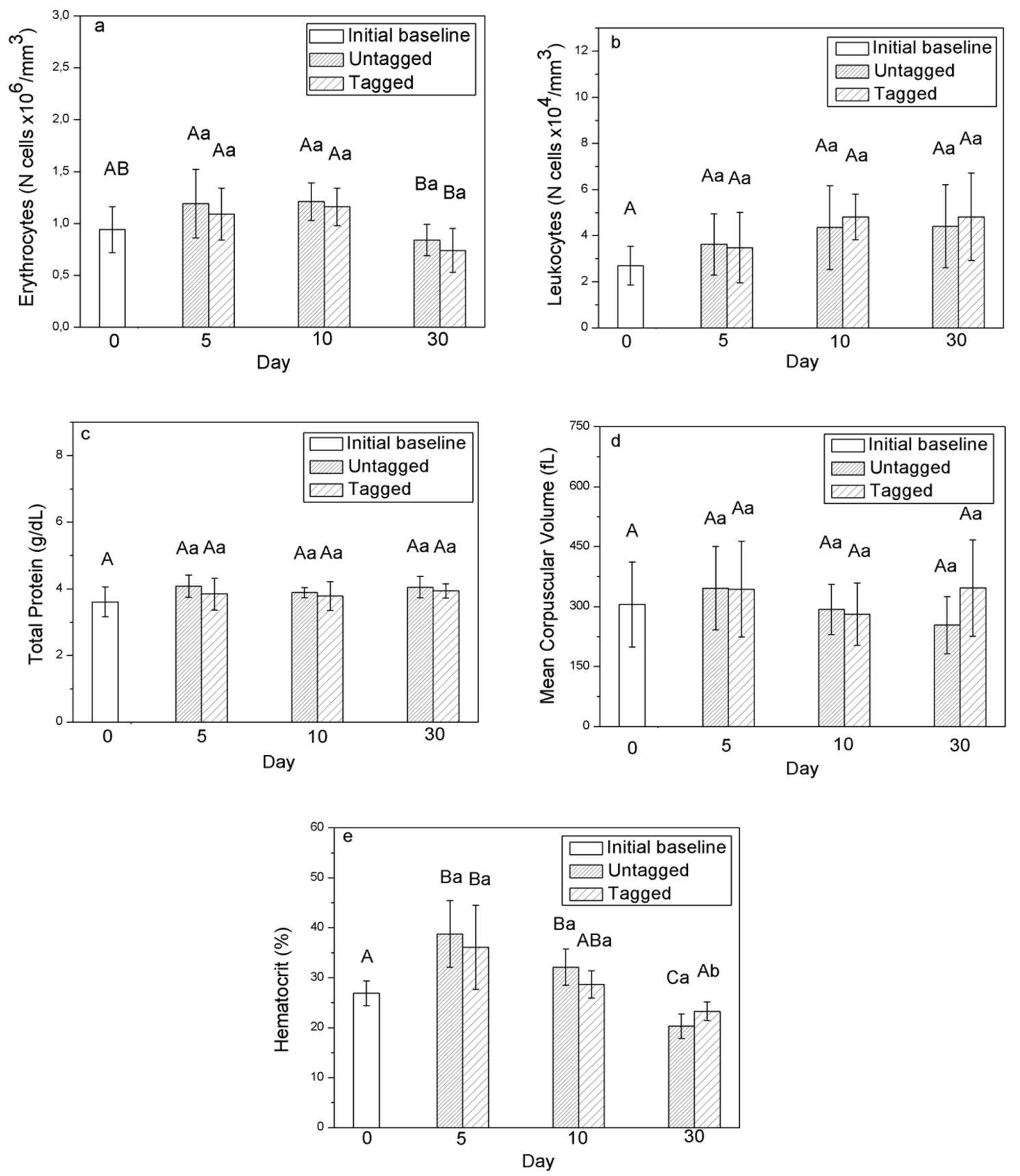

Fig. 4. Hematological parameters of tagged and untagged Lophiosilurus alexandri on the different days analyzed: a. Er. b. Leuk. c. TPP. d. MCV. e. Htc. Means followed by different capital letters differ significantly $(p<0.05)$ between days by twoway ANOVA followed by Tukey test. Means with different lowercase letters differ significantly $(p<0.05)$ between tagged and untagged fish by Student's t-test.

mortality. This suggests that, even if in another environment, if the tag is detached the animals have the capacity to recover.

The hematological values of the present study are consistent with those described previously for the same species, including values reported for erythrocytes and leukocytes by Mattioli et al. (2017), hematocrit by Kitagawa et al. (2015) and plasmatic protein by Costa et al. (2016). The increase in the number of erythrocytes and hematocrit on the fifth and tenth day after tagging may be related to stress caused dur- ing the management of the fish, since they took eight days to start feeding. However, on the thirtieth day the values returned to basal levels, indicating adaptation to the tags. The increase in hematocrit concentration may also be indicative of greater physical effort during a stressful situation (Acerete et al., 2004). Similar results were described by Lewis, Muntz (1984) and Steinhausen et al. (2006), that evaluated the influence of external tags containing batteries and signal transmitters on fish parameters. In both experiments was 
observed that evenusing heavy tags, that interfere in the fish behavior (opercular movement and swimming), and no effects were observed on the hematological parameters.

The tag used in the study for the period of 90 days reduced growth performance when applied to juvenile $L$. alexandri of the Small size class but did not interfere in the growth performance of juvenile fish in the Medium and Large size classes.

The retention rate of the tag increased with increasing size of the animals, reaching $84.83 \%$ at the end of 90 days for the Large size class. The hematocrit of animals of 64.28 $\pm 11.80 \mathrm{~g}$ was higher in the first days, indicating a situation of stress, but it recovered by the end of 30 days. On the other hand, no changes were found for total plasma protein, leukocytes, erythrocytes and mean corpuscular volume. This finding shows that the tag can be used without causing major influences on hematocrit, plasma protein, erythrocytes, leukocytes and mean corpuscular volume of $L$. alexandri.

\section{Acknowledgment}

We thank CAPES-Brazil, CNPq-Brazil and FAPEMIGBrazil for financial support.

\section{References}

Acerete L, Balasch JC, Espinosa E, Josa A, Tort L. Physiological responses in Eurasian perch (Perca fluviatilis, L.) subjected to stress by transport and handling. Aquaculture. 2004; 237(1-4):167-78. Available from: https://doi.org/10.1016/j. aquaculture.2004.03.018

Adeyemo OK. Haematological profile of Clarias gariepinus(Burchell, 1822) Exposed to Lead. Turkish J Fish Aquat Sci. 2007; 7: 16369. Available from: http://www.trjfas.org/uploads/pdf_328.pdf

Agostinho AA, Pelicice FM, Gomes LC, Júlio HF. Reservoir fish stocking: When one plus one may be less than two. Natureza \& Conservação. 2010; 8(2):103-11. Available from: https://doi. org/10.4322/natcon.00802001

Alves CBM. Evaluation of fish passage through the Igarapé Dam fish ladder (rio Paraopeba, Brazil), using marking and recapture. Neotrop Ichthyol. 2007; 5(2):233-36. Available from: https://doi.org/10.1590/S1679-62252007000200019

Auer NA. Importance of habitat and migration to sturgeons with emphasis on lake sturgeon. Can J Fish Aquat Sci. 1996; 53(S1):152-60. Available from: https://doi.org/10.1139/f95-276

Barroca TM, Gutiérrez-Espinosa MA, Giraldo A, Bedore AG, Godinho AL. Coded wire tagging of juvenile curimbatá, Prochilodus lineatus (Valenciennes, 1837) (Characiformes): mortality, tag retention, and growth. Neotrop Ichthyol. 2015; 13(2):383-8. Available from: https://doi.org/10.1590/19820224-20140074

Barros MDM, Guimarães-cruz RJ, Veloso-júnior VC, Santos JE. Reproductive apparatus and gametogenesis of Lophiosilurus alexandri Steindachner (Pisces, Teleostei, Siluriformes). Rev Bras Zool. 2007; 24(1):213-21. Available from: http://dx.doi. org/10.1590/S0101-81752007000100028

Bodine KA, Fleming P. Retention of PIT and T-Bar Anchor Tags in Blue Catfish. N Am J Fish Manag. 2014; 34(1):68-71. Available from: https://doi.org/10.1080/02755947.2013.860064
Booth AJ, Weyl OLF. Retention of T-bar anchor and dart tags by a wild population of African sharptooth catfish, Clarias gariepinus. Fish Res. 2008; 92(2-3):333-39. Available from: https://doi.org/10.1016/j.fishres.2008.02.002

Brennan NP, Leber KM, Blackburn BR. Use of coded-wire and visible implant elastomer tags for marine stock enhancement with juvenile red snapper Lutjanus campechanus. Fish Res. 2007; 83(1):90-7. Available from:https://doi.org/10.1016/j. fishres.2006.08.021

Brewer RS, Norcross BL. Long-term retention of internal elastomer tags in a wild population of North Pacific giant octopus (Enteroctopus dofleini). Fish Res. 2012; 134-136:17-20. Available from: https://doi.org/10.1016/j.fishres.2012.07.020

Brown RS, Cooke SJ, Anderson WG, Mckinley RS. Evidence to Challenge the " $2 \%$ Rule" for Biotelemetry. N Am J Fish Manag. 1999; 19(3):867-71. Available from: https://doi. org/10.1577/1548-8675(1999)019<0867:ETCTRF >2.0.CO;2

Cardoso EL, Chiarini-Garcia H, Ferreira RMA, Poli CR. Morphological changes in the gills of Lophiosilurus alexandri exposed to un-ionized ammonia. J Fish Biol. 1996; 49(5):77887. Available from: https://doi.org/10.1111/j.1095-8649.1996. tb00078.x

Costa DP, Leme FOP, Takata R, Costa DC, Silva WS, Filho RM, Alves GM, Luz RK. Effects of temperature on growth, survival and physiological parameters in juveniles of Lophiosilurus alexandri, a carnivorous neotropical catfish. Aquac Res. 2016; 47(6):170615. Available from: https://doi.org/10.1111/are.12594

Counihan TD, Frost CN. Influence of externally attached transmitters on the swimming performance of juvenile white sturgeon. Trans Am Fish Soc.1999; 128(5):965-70. Available from: https://doi. org/10.1577/1548-8659(1999)128<0965:IOEATO >2.0.CO;2

Food and Agriculture Organization of the United Nations (FAO). The state of world fisheries and aquaculture. Contributing to foof security and nutrition for all. Rome. 2016. Available from: http://www.fao.org/3/a-i5555e.pdf

Frederick JL. Evaluation of fluorescent elastomer injection as a method for marking small fish. Bull Mar Sci. 1997; 61(2):399408. Available from: https://doi.org/10.1577/M06-157.1

Gibbons JW, Andrews KM. PIT tagging: simple technology at its Best. BioScience. 2004; 54(5):447-54. Available from: https:// doi.org/10.1641/0006-3568(2004)054[0447:PTSTAI]2.0.CO;2

Gil MDM, Palmer M, Grau A, Massutí E, Pastor E. Comparing tagging strategies: Effects of tags on retention rate, mortality rate and growth in hatchery-reared juvenile meagre, Argyrosomus regius (Pisces: Sciaenidae). Sci Mar. 2017; 81(2):171-78. Available from: doi: http://dx.doi.org/10.3989/scimar.04583.26B

Goldenfarb PB, Bowyer FP, Hall E, Brosious E. Reproducibility in the Hematology Laboratory: The Microhematocrit Determination. Am J Clin Pathol. 1971;56(1):35-39. Available from: https://doi.org/10.1093/ajcp/56.1.35

Greenstreet SPR, Morgan RIG. The effect of ultrasonic tags on the growth rates of Atlantic salmon, Salmo salar L., parr of varying size just prior to smolting. J Fish Biol. 1989; 35(2):30109. Available from: https://doi.org/10.1111/j.1095-8649.1989. tb02979.x

Griffiths SP. Retention of visible implant tags in small rockpool fishes. Mar Ecol Prog Ser. 2002; 236:307-09. Available from: doi: $10.3354 /$ meps 236307

Halls AS, Azim ME. The utility of visible implant (VI) tags for marking tropical river fish. Fish Manag Ecol. 1998; 5(1):71-80. Available from: https://doi.org/10.1046/j.13652400.1998.00085.x 
Instituto Chico Mendes de Conservação da Biodiversidade (ICMBio). Executive summary Brazil Red Book of Threatened Species of Fauna. Brasília. 2016. Available from: http://www. icmbio.gov.br/portal/images/stories/comunicacao/publicacoes/ publicacoes-diversas/dcom_sumario_executivo_livro vermelho_ed 2016.pdf

Jepsen N, Schreck C, Clements S, Thorstad EB. A brief discussion on the $2 \%$ tag/bodymass rule of thumb. Aquatic telemetry: advances and applications: Proceedings of the Fifth Conference on Fish Telemetry held in Europe. Ustica. 2003. Available from: http://www.fao.org/tempref/docrep/fao/008/y5999e/ y5999e25.pdf

Jepsen N, Thorstad EB, Havn T, Lucas MC. The use of external electronic tags on fish: An evaluation of tag retention and tagging effects. Animal Biotelemetry. 2015; 3(49):1-23. Available from: https://doi.org/10.1186/s40317-015-0086-z

Johnston RJ, Holland DS, Maharaj V, Campson TW. Fish harvest tags: An alternative management approach for recreational fisheries in the US Gulf of Mexico. Mar Policy. 2007; 31(4):505-16: Available from: https://doi.org/10.1016/j. marpol.2006.12.004

Kawamura K, Furukawa M, Kubota M, Harada Y. Effects of stocking hatchery fish on the phenotype of indigenous populations in the amago salmon Oncorhynchus masou ishikawae in Japan. J Fish Biol. 2012; 81(1):94-109. Available from: https://doi. org/10.1111/j.1095-8649.2012.03315.x

Kitagawa AT, Costa LS, Paulino RR, Luz RK, Rosa PV, GuerraSantos B, Fortes-Silva R. Feeding behavior and the effect of photoperiod on the performance and hematological parameters of the pacamã catfish (Lophiosilurus alexandri). Appl Anim Behav Sci. 2015; 171:211-08. Available from: https://doi. org/10.1016/j.applanim.2015.08.025

Krystan R, Grant DVM. Fish hematology and associated disorders. Clin Lab Med. 2015; 35(3):681-701. Available from: https://doi.org/10.1016/j.cll.2015.05.015

Lewis AE, Muntz WRA. The effects of external ultrasonic tagging on the swimming performance of rainbow trout, Salmo gairdneri Richardson. J Fish Biol. 1984; 25(5):57785. Available from: https://doi.org/10.1111/j.1095-8649.1984. tb04904.x

Mattioli CC, Takata R, Leme FOP, Costa DC, Filho RM, Silva WS, Luz RK. The effects of acute and chronic exposure to water salinity on juveniles of the carnivorous freshwater catfish Lophiosilurus alexandri. Aquaculture. 2017; 481:255-66. Available from: https://doi.org/10.1016/j. aquaculture.2017.08.016

Mcdougall CA, Pisiak DJ, Barth CC, Blanchard MA, MacDonell DS, Macdonald D. Relative recruitment success of stocked age-1 vs age-0 lake sturgeon (Acipenser fulvescens Rafinesque, 1817) in the Nelson River, northern Canada. J Appl Ichthyol. 2014; 30(6):1451-60. Available from: https://doi.org/10.1111/ jai. 12555

Navarro A, Oliva V, Zamorano MJ, Ginés R, Izquierdo MS, Astorga N, Afonso JM. Evaluation of PIT system as a method to tag fingerlings of gilthead seabream (Sparus auratus L.): Effects on growth, mortality and tag loss. Aquaculture. 2006; 257(1-4):309-15. Available from: https://doi.org/10.1016/j. aquaculture.2006.02.072

Phelps RP, Rodriguez D. Effects of tag type on red snapper Lutjanus campechanus tag retention, growth and survival under hatchery conditions. J Appl Ichthyol. 2011; 27(5):116972. Available from: doi: 10.1111/j.1439-0426.2011.01787.x
Rikardsen AH. Effects of floy and soft VIalpha tags on growth and survival of juvenile Arctic Char. N Am J Fish Manag. 2000; 20(3):720-9. Available from: https://doi.org/10.1577/15488675(2000)020<0720:EOFASV $>2.3 . C O ; 2$

Rikardsen AH, Woodgate M, Thompson DA. A comparison of floy and soft VIalpha tags on hatchery Arctic charr, with emphasis on tag retention, growth and survival. Environ Biol Fishes. 2002; 64(1-3):269-73. Available from: https://doi. org/10.1023/A:1016037921211

Rudershausen PJ, Buckel JA, Hightower JE, Jech JM. Estimating reef fish discard mortality using surface and bottom tagging: effects of hook injury and barotrauma. Can J Fish Aquat Sci. 2014; 71(4):514-20. Available from: https://doi.org/10.1139/ cjfas-2013-0337

Sato Y. Catálogo Produção Científica apoiada pelo Centro Integrado de Recursos Pesqueiros e Aquicultura de Três Marias. 2014; 1980-2013. Brasília.

Smircich MG, Kelly J. Extending the 2\% rule: The effects of heavy internal tags on stress physiology, swimming performance, and growth in brook trout. Animal biotelemetry. 2014; 16(2):1-7. Available from: doi: 10.1186/2050-3385-2-16

Smith NJ, McCall PL, Sutton TM. Effects of different tagging protocols on survival, growth, and tag retention in juvenile least cisco Coregonus sardinella. Fish Res. 2017; 187:68-72. Available from: https://doi.org/10.1016/j.fishres.2016.11.008

Specziár A, Turcsányi S. Effect of stocking strategy on distribution and recapture rate of common carp Cyprinus carpio L., in a large and shallow temperate lake: implications for recreational put-and-take fisheries management. J Appl Ichthyol. 2014; 30(5):887-94. Available from: https://doi.org/10.1111/jai.12488

Steffensen KD, Powell LA, Koch JD. Assessment of hatcheryreared pallid sturgeon survival in the Lower Missouri River. N Am J Fish Manag. 2010; 30(3):671-78. Available from: https:// doi.org/10.1577/M09-151.1

Steinhausen MF, Andersen NG, Steffensen JF. The effect of external dummy transmitters on oxygen consumption and performance of swimming Atlantic cod. J Fish Biol. 2006; 69(3):951-956. Available from: https://doi.org/10.1111/j.10958649.2006.01143.x

Strand R, Finstad B, Lamberg A, Heggberget TG. The effect of Carlin tags on survival and growth of anadromous Arctic charr, Salvelinus alpinus. Environ Biol Fishes. 2002; 64 (1-3):27580. Available from: https://doi.org/10.1023/A:1016091619937

Sumpton W, Mayer D, Brown I, Sawynok B, Mclennan M, Butcher A, Kirkwood J. Investigation of movement and factors influencing post-release survival of line-caught coral reef fish using recreational tag-recapture data. Fish Res. 2008; 92(2-3):189-95. Available from: https://doi.org/10.1016/j. fishres.2008.01.019

Sutton TM, Benson AC. Influence of external transmitter shape and size on tag retention and growth of juvenile lake sturgeon. Trans Am Fish Soc. 2003; 123(6):1257-63. Available from: https://doi.org/10.1577/T03-001

Svåsand T, Kristiansen TS, Pedersen T, Salvanes AGV, Engelsen R, Naevdal G, Nødtvedt M. The enhancement of cod stocks Fish Fish. 2000; 1(2):173-205. Available from: https://doi. org/10.1046/j.1467-2979.2000.00017.x

Tavares-Dias M, de Moraes FR. Leukocyte and thrombocyte reference values for channel catfish (Ictalurus punctatus), with an assessment of morphologic, cytochemical, and ultrastructural features. Vet Clin Pathol. 2007; 36(1):4954. Available from: 10.1111/j.1939-165X.2007.tb00181.x 
Thorsteinsson V, Arnold G, Davenport J, Maoiléidigh NÓ. Tagging methods for stock assessment and research in fisheries. Report of Concerted Action FAIR CT.96.1394 (CATAG). Reykjavík 2002. Available from:http://nosb.org/wp-content/ uploads/2010/11/Manual-on-Fish-Tagging.pdf

Verdegem MCJ, Hilbrands AD, Boon JH. Influence of salinity and dietary composition on blood parameter values of hybrid red tilapia, Oreochromis niloticus (Linnaeus) x $O$. Mossambicus (Peters). Aquac Res. 1997; 28(6):4539. Available from: 10.1046/j.1365-2109.1997.00880.x

Ward DL, Childs MR, Persons WR. PIT tag retention and tag induced mortality in juvenile bonytail and Gila chub. Fish Manag Ecol. 2008; 15(2):159-61. Available from: https://doi. org/10.1111/j.1365-2400.2008.00595.x

Winner BL, McMichael RH, Brant LL. Evaluation of small T-anchor and dart tags for use in marking hatchery-reared juvenile red drum, Sciaenops ocellatus. Fish Bull. 1999; 97(3):730-05. Available from: https://spo.nmfs.noaa.gov/sites/ default/files/28winner.pdf
Woods CMC, Martin-Smith KM. Visible implant fluorescent elastomer tagging of the big-bellied seahorse, Hippocampus abdominalis. Fish Res. 2004; 66(2-3):363-71. Available from: https://doi.org/10.1016/S0165-7836(03)00183-8

Zeeh KM, Wood JB. Impact of visible implant elastomer tags on the growth rate of captive Caribbean reef squid Sepioteuthis sepioidea. Fish Res. 2009; 95(2-3):362-04. Available from: https://doi.org/10.1016/j.fishres.2008.08.002
Submitted December 03, 2018 Accepted March 08, 2019 by Paulo Pompeu 